\title{
PENGARUH PENGGUNAAN METODE PEMBELAJARAN ACTIVE LEARNING TIPE QUIZ TEAM TERHADAP PENINGKATAN HASIL BELAJAR SISWA KELAS X APK 3 SMK NEGERI 1 SURABAYA PADA KOMPETENSI DASAR MENERAPKAN KETERAMPILAN KOMUNIKASI LISAN
}

\author{
HARDIANI \\ SMKN 1 Surabaya \\ e-mail: hardiani0366@gmail.com
}

\begin{abstract}
ABSTRAK
Metode penelitian pada penelitian ini adalah metode deskriptif. Sedangkan bentuk penelitian pada penelitian ini adalah penelitian tindakan kelas. Sampel penelitian ini adalah 31 orang. Hasil analisis data menunjukkan bahwa peningkatan kemampuan guru dalam munyusun RPP dari siklus 1 sampai siklus 2. Peningkatan hasil belajar komunikasi siswa sudah dapat dicapai, hal ini dapat dilihat dari adanya peningkatan hasil belajar siswa. Sebelumnya, pada hasil pretest tidak ada satupun siswa yang memenuhi nilai KKM dan rata-rata hasil belajar sebesar 58.7 dengan prosentase kelulusan $0 \%$. Namun, di siklus pertama rata-rata hasil belajar siswa yaitu 73.5 dengan prosentase kelulusan jumlah siswa yang telah mencapai KKM mencapai 35\%. Kemudian, di siklus kedua rata-rata hasil belajar siswa yaitu 91.2 81 dengan prosentase kelulusan jumlah siswa yang telah mencapai KKM mencapai 100\%. Data ini menunjukkan bahwa metode pembelajaran Active Learning tipe Quiz Team telah berhasil membantu siswa untuk memenuhi Standar Ketuntasan Minimal sebesar 75.
\end{abstract}

Kata Kunci: Penelitian Tindakan Kelas, Model Pembelajaran, Active Learning Tipe Quiz Team.

\section{PENDAHULUAN}

Nilai hasil belajar adalah salah satu indikator yang bisa digunakan untuk mengukur keberhasilan belajar seseorang. Nilai hasil belajar mencerminkan hasil yang dicapai seseorang dari segi kognitif, afektif, maupun psikomotorik. Dalam proses belajar mengajar, ada banyak faktor yang mempengaruhi pencapaian nilai hasil belajar siswa, baik yang berasal dari dalam diri siswa (internal) maupun dari lingkungan luar (eksternal). Faktor internal terkait dengan disiplin, respon dan motivasi siswa, sementara faktor eksternal adalah lingkungan belajar, tujuan pembelajaran, kreatifitas pemilihan media belajar oleh pendidik serta metode pembelajaran. Faktor-faktor tersebut mempengaruhi satu sama lain dan merupakan satu kesatuan yang mendasari hasil belajar siswa. Dari semua faktor yang ada, metode pembelajaran yang dipilih oleh seorang pendidik menjadi sumber dan berkait dengan faktor yang lain. Pemilihan metode pembelajaran yang tepat akan membawa suasana belajar yang menyenangkan dan memungkinkan siswa untuk mengembangkan kreatifitas.

Suasana belajar yang menyenangkan akan membawa dampak pada motivasi belajar dan disiplin yang meningkat. Motivasi belajar yang tinggi menjadi salah satu faktor penentu keberhasilan siswa dalam mencapai hasil belajar yang terbaik. Berdasarkan hasil pengamatan di SMK Negeri 1 Surabaya khususnya untuk kelas X APK 3, pada pembelajaran Keterampilan Dasar Komunikasi, proses belajar mengajar di kelas dilakukan dengan metode konvensional (ceramah). Ketika proses pembelajaran tersebut berlangsung, banyak siswa yang mengantuk atau mengobrol. Rasa ingin tahu siswa tidak terbangun, kemandirian dalam kegiatan pembelajaran pun sedikit sekali terlihat. Ketekunan yang dimiliki belum tampak.

Selain itu hanya ada beberapa siswa yang aktif di kelas, mereka mengajukan beberapa pertanyaan yang berkaitan dengan materi yang telah diajarkan, namun masih banyak siswa yang hanya menjadi pendengar dan tergolong pasif di kelas. Saat mendapatkan nilai yang tidak memuaskan seakan menjadi hal yang biasa bagi siswa. Siswa tidak termotivasi dalam melakukan kegiatan pembelajaran. Jika hal demikian didiamkan saja oleh guru dan tidak diupayakan adanya 
perbaikan maka tujuan kegiatan pembelajaran tersebut tentu tidak akan dapat tercapai dengan maksimal.

\section{METODE PENELITIAN}

Rancangan siklus penelitian ini menggunakan model Kemmis dan Taggart. Prosedur kerja dalam penelitian tindakan menurut Kemmis \& Taggart dalam Arikunto (2006), meliputi tahaptahap sebagai berikut:

1. Perencanaan (planning)

2. Tindakan (acting)

3. Observasi (observing)

4. Refleksi (reflecting)

Selanjutnya siklus tersebut akan berulang terus sehingga membentuk spiral. Banyaknya siklus yang dilakukan tergantung pada peningkatan hasil belajar. Proses siklus akan berhenti pada saat siswa sudah mengalami peningkatan hasil belajar. Dalam penelitian ini, peneliti berencana untuk melakukan 3 kali siklus tindakan.

\section{HASIL DAN PEMBAHASAN}

Penelitian tindakan kelas ini diterapkan pada mata pelajaran Keterampilan Dasar Komunikasi kelas X APK 3. Biasanya, dalam pelaksanaan rangkaian siklus pertama ditemukan kendala-kendala sehingga tujuan penelitian belum dapat terlaksana. Oleh sebab itu, diadakan rangkaian siklus kedua dengan harapan siklus kedua dapat mewujudkan tujuan penelitian dengan belajar menganalisis kendala-kendala yang ditemui pada siklus pertama. Namun, apabila pada siklus kedua hasil yang didapat belum juga memenuhi tujuan penelitian, maka diadakan siklus selanjutnya sampai tujuan tercapai. Namun sebaliknya, apabila pada siklus kedua tujuan hasil penelitian sudah dapat terwujud maka penelitian dapat berhenti. Dalam penelitian ini, meskipun peneliti merencanakan untuk menggunakan 3 kali siklus penelitian, tetapi karena pada siklus ke dua sudah mulai terdapat peningkatan hasil belajar siswa, maka akhirnya peneliti memutuskan berhenti pada siklus kedua, dan tidak melanjutkan pada siklus ketiga.

\section{Kondisi Pra Siklus}

Kondisi pra siklus merupakan kondisi dimana siswa belum memperoleh perlakuan penelitian tindakan, rangkaian pembelajaran yang digunakan di dalam kelas belum menggunakan metode pembelajaran Active Learning tipe Quiz Team. Sebelum melakukan penelitian, peneliti terlebih dahulu melakukan pengamatan terhadap keadaan kelas, siswa dan guru selama proses pembelajaran. Saat peneliti mengadakan pengamatan, terlihat beberapa siswa tidak memperhatikan pelajaran Keterampilan Dasar Komunikasi yang disampaikan oleh guru, hanya beberapa siswa yang aktif untuk menjawab pertanyaan yang diajukan guru tentang materi komunikasi yang sedang dibahas, siswa juga tidak aktif saat berdiskusi dengan guru, siswa terlihat tidak antusias saat pembelajaran komunikasi berlangsung, metode belajar yang biasa digunakan saat itu adalah metode ceramah, dimana guru bertindak sebagai sumber utama dan siswa hanya bertindak sebagai pendengar. Dengan metode ceramah, ternyata hasil yang diperoleh kurang memuaskan, selain itu tingkat pemahaman siswa yang tidak tumbuh selama proses pembelajaran, dimana rata-rata hasil belajar mata pelajaran Keterampilan Dasar Komunikasi yang rendah yaitu 58,7 hal ini dapat diketahui dari hasil tes pra siklus siswa yang belum mencapai KKM yang ditetapkan sekolah yaitu 75.

\section{Kondisi Siklus 1}

Standar Kompetensi yang diajarkan pada siklus pertama ini adalah Mengaplikasikan Keterampilan Dasar Komunikasi. Dengan Kompetensi Dasar Identifikasi proses 
komunikasi di tempat kerja. Materi pokok yang diberikan pada siklus ini adalah mengenai teknik berbicara efektif, teknik bertanya efektif dan teknik membaca efektif.

Hal utama yang dilakukan dalam proses tindakan pada siklus 1, dan yang membedakan dengan siklus berikutnya adalah:

1) Anggota kelompok dipilih berdasarkan kemampuan akademis, untuk menghindari kecemburuan.

2) Pelaksanaa kuis dilakukan dengan cara kelompok A diminta untuk menyiapkan quiz beserta jawaban singkat, sementara kelompok B dan C diminta untuk kembali membuka pelajaran untuk persiapan menjawab quis yang sudah disiapkan oleh kelompok A.

3) Pengajar tidak menggunakan alat bantu dalam proses belajar.

4) Hasil observasi siklus pertama:

5) Pada saat kuis berlangsung ada beberapa anggota tim yang tidak mau aktif untuk mengikuti jalannya kuis. Hal ini dapat dilihat dari tim yang bertugas untuk membuat soal (pemandu kuis) tidak semua anggota tim membuat soal tersebut. Kemudian dari tim yang bertugas untuk menjawab soal (peserta kuis) juga tidak semua anggota tim bekerja sama dalam menjawab soal, artinya hanya beberapa siswa saja yang menjawab.

6) Hanya ada beberapa siswa yang aktif dan mendominasi kegiatan belajar mengajar, baik saat pemberian materi maupun pada saat pelaksanaan Quiz Team.

7) Saat menerangkan materi, peneliti harus lebih sering memberikan pertanyaan kepada siswa untuk memancing pengetahuan dan mengasah pemahaman siswa.

8) Sementara dari hasil Refleksi siklus pertama dapat disimpulkan bahwa kegiatan pembelajaran pada siklus pertama belum berhasil secara maksimal. Hal ini dapat dilihat dari pencapaian hasil belajar yang masih di bawah KKM. Hanya ada 30 \% siswa yang berhasil mendapat nilai sesuai dengan KKM, dengan rata-rata hasil belajar kelas : 73,5. Ini berarti bahwa pencapaian nilai masih dibawah standar KKM. Selain itu hasil analisis lebih lanjut ternyata siswa belum terbiasa dengan metode pembelajaran Active Learning tipe Quiz Team. Hasil siklus pertama ini kemudian dijadikan pijakan untuk merencanakan tindakan pada siklus kedua.

\section{Kondisi Siklus kedua}

Standar Kompetensi yang diajarkan pada siklus kedua ini adalah Mengaplikasikan Keterampilan Dasar Komunikasi. Dengan Kompetensi Dasar identifikasi proses komunikasi di tempat kerja. Materi pokok yang diberikan pada siklus ini adalah mengenai Teknik mendengarkan secara aktif, Teknik teknik menulis efektif dan Pertanyaan dan instruksi dijawab dan diikuti secara tepat dan cepat.

Hasil observasi dan refleksi pada siklus pertama digunakan sebagai dasar tindakan pada siklus kedua dalam rangka untuk lebih menyemangati siswa dan diharapkan dapat meningkatkan hasil belajar agar sesuai dengan target KKM. Tindakan yang dilakukan pada siklus kedua dan membedakan dengan siklus pertama adalah:

1) Kelompok dibuat secara acak tanpa melihat kemampuan akademik siswa.

2) Teknik quiz dilakukan dengan melibatkan seluruh siswa untuk menjawab secara individu dan tidak secara kelompok.

3) Pengajar mulai menggunakan bantuan LCD dalam proses belajar mengajar.

Berdasarkan hasil pengamatan kolaborator pada siklus kedua, ada beberapa perbaikan atas kendala yang dihadapi pada siklus pertama, hal ini dapat dijabarkan sebagai berikut:

1) Siswa sudah mampu untuk diajak bekerjasama dalam kegiatan pembelajaran. Hal ini dapat diamati karena adanya perubahan sikap yaitu adanya sikap tanggung jawab yang ditunjukkan oleh siswa baik secara individu maupun tim. 
2) Sudah banyak siswa yang aktif dalam kegiatan pembelajaran dan tidak ada yang mendominasi kegiatan belajar. Hal ini dapat dilihat dari banyaknya siswa yang aktif baik pada saat proses pembelajaran berlangsung maupun pada pelaksanaan Quiz Team.

3) Siswa sangat antusias mengikuti pembelajaran di kelas. Hal ini dapat terlihat dari semangat siswa saat bersaing untuk memperoleh poin yang tinggi di dalam timnya.

4) Manajemen kelas sudah baik dibandingkan dengan siklus sebelumnya. Hal ini dikarenakan adanya pemanfaatan media LCD (Liquid Crystal Display) yang digunakan selama proses pembelajaran.

5) Peneliti juga sudah sering memberikan pertanyaan kepada siswa mengenai materi yang telah diajarkan.

6) Peningkatan hasil belajar komunikasi siswa sudah dapat dicapai.

Hal ini dapat dilihat dari adanya peningkatan hasil belajar siswa. Sebelumnya pada hasil pree test tidak ada satupun siswa yang memenuhi nilai KKM dan rata-rata hasil belajar sebesar 58.7 dengan prosentase kelulusan $0 \%$. Namun, di siklus pertama rata-rata hasil belajar siswa yaitu 73.5 dengan prosentase kelulusan jumlah siswa yang telah mencapai KKM mencapai $35 \%$. Kemudian, di siklus kedua rata-rata hasil belajar siswa yaitu 91.2 dengan prosentase kelulusan jumlah siswa yang telah mencapai KKM mencapai 100\%. Data ini menunjukkan bahwa metode pembelajaran Active Learning tipe Quiz Team telah berhasil membantu siswa untuk memenuhi Standar Ketuntasan Minimal (SKM) sebesar 75. Hasil reflesi siklus kedua menyimpulkan bahwa kegiatan pembelajaran pada siklus kedua sudah menunjukkan adanya peningkatan dari siklus sebelumnya. Hal ini dapat dilihat dari adanya peningkatan hasil test kognitif siswa pada siklus kedua dengan prosentase kelulusan jumlah siswa yang telah mencapai KKM mencapai $100 \%$. Selain itu, partisipasi siswa dalam pembelajaran berlangsung lebih aktif dibandingkan dengan siklus sebelumnya, siswa sudah berani untuk mengungkapkan pendapatnya dalam kegiatan belajar. Proses Quiz Team berjalan sesuai dengan langkah-langkah yang ditentukan sebelum dan siswa pun sangat antusias untuk memperoleh poin yang tinggi dalam Quiz Team.

Selain itu dalam refleksi siklus kedua ini Peneliti bersama kolaborator menilai, karena dalam siklus kedua ini kelas sudah mencapai hasil belajar yang baik dan pelaksanaan yang berjalan dengan lancar, maka diputuskan untuk menghentikan penelitian tindakan kelas ini hanya sampai pada siklus kedua. Penelitian dicukupkan sampai dengan siklus kedua karena telah terdapat peningkatan jumlah siswa yang telah memenuhi Kriteria Ketuntasan

Minimal (KKM) yang ditetapkan sekolah sebesar 75. Nilai pencapaian hasil belajar siswa untuk masing-masing siklus dapat dilihat pada tabel dibawah ini:

Tabel 1. Data Pencapaian Hasil Belajar Siswa

\begin{tabular}{|l|l|l|}
\hline Siklus & $\begin{array}{l}\text { Rata-Rata Hasil } \\
\text { Belajar }\end{array}$ & $\begin{array}{l}\text { \% Siswa yg Mencapai } \\
\text { KKM }\end{array}$ \\
\hline Pra Siklus & 56,7 & $0 \%$ \\
\hline Siklus 1 & 73,5 & $35 \%$ \\
\hline Siklus 2 & 91,2 & $100 \%$ \\
\hline
\end{tabular}

Peningkatan hasil belajar siswa dengan menggunakan metode pembelajaran Active Learning tipe Quiz Team pada mata pelajaran Keterampilan Dasar Komunikasi di SMK Negeri 1 Surabaya, bertujuan untuk melihat adanya hubungan antara penerapan metode pembelajaran Active Learning tipe Quiz Team dengan hasil belajar siswa pada mata pelajaran Keterampilan Dasar Komunikasi. Penerapan Quiz Team juga memberikan stimulus kepada siswa untuk aktif didalam pembelajaran, selain itu menumbuhkan rasa tanggung jawab untuk memahami lebih dalam akan materi yang telah diajarkan sebelumnya. Dari hasil penelitian yang dilakukan diantaranya dengan 
menggunakan teknik observasi, metode pembelajaran Active Learning tipe Quiz Team dapat meningkatkan kemampuan kognitif siswa, hal ini terlihat dari hasil tes yang selalu mengalami peningkatan.

Selain bertujuan untuk meningkatkan hasil belajar secara kognitif, penerapan metode pembelajaran Active Learning tipe Quiz Team juga dapat merangsang antusiasnya dalam belajar serta menyenangkan bagi siswa. Metode pembelajaran ini menekankan kepada aktivitas siswa secara optimal untuk memperoleh hasil belajar berupa perpaduan antara aspek kognitif, afektif dan psikomotor secara seimbang. Dari data yang disajikan pada tabel 1 dapat dilihat adanya peningkatan hasil belajar siswa.

Sebelumnya, dari hasil pre test tidak ada satupun siswa yang memenuhi nilai KKM dan rata-rata hasil belajar sebesar 58.7 dengan prosentase kelulusan $0 \%$. Namun, di siklus pertama ratarata hasil belajar siswa yaitu 73.5 dengan prosentase kelulusan jumlah siswa yang telah mencapai KKM mencapai 35\%. Kemudian, di siklus kedua rata-rata hasil belajar siswa yaitu 91.2 dengan prosentase kelulusan jumlah siswa yang telah mencapai KKM mencapai 100\%. Data ini menunjukkan bahwa metode pembelajaran Active Learning tipe Quiz Team telah berhasil membantu siswa untuk memenuhi Standar Ketuntasan Minimal (SKM) sebesar 75.

\section{KESIMPULAN}

Berdasarkan pada hasil penelitian pelaksanaan tindakan yang telah dilakukan dalam penerapan metode pembelajaran Active Leaning tipe Quiz Team pada mata pelajaran Keterampilan Dasar Komunikasi di SMK Negeri 1 Surabaya, maka dapat ditarik kesimpulan sebagai berikut:

a. Sebelum adanya penerapan metode pembelajaran Active Learning tipe Quiz Team di kelas, hanya beberapa siswa yang aktif, siswa kurang antusias mengikuti jalannya proses pembelajaran dan hasil belajar siswa pada mata pelajaran Keterampilan Dasar Komunikasi pun rendah.

b. Penerapan metode pembelajaran Active Learning tipe Quiz Team, dapat meningkatkan kemampuan akademik siswa dapat secara optimal pada mata pelajaran Keterampilan Dasar Komunikasi kelas X APK 3 di SMK Negeri 1 Surabaya.

c. Peningkatan hasil belajar komunikasi siswa sudah dapat dicapai, hal ini dapat dilihat dari adanya peningkatan hasil belajar siswa. Sebelumnya, pada hasil pretest tidak ada satupun siswa yang memenuhi nilai KKM dan rata-rata hasil belajar sebesar 58.7 dengan prosentase kelulusan 0\%. Namun, di siklus pertama rata-rata hasil belajar siswa yaitu 73.5 dengan prosentase kelulusan jumlah siswa yang telah mencapai KKM mencapai 35\%. Kemudian, di siklus kedua rata-rata hasil belajar siswa yaitu 91.2 81 dengan prosentase kelulusan jumlah siswa yang telah mencapai KKM mencapai 100\%. Data ini menunjukkan bahwa metode pembelajaran Active Learning tipe Quiz Team telah berhasil membantu siswa untuk memenuhi Standar Ketuntasan Minimal (SKM) sebesar 75.

d. Penerapan metode pembelajaran Active Learning tipe Quiz Team telah mampu meningkatkan kemampuan tanggung jawab peserta didik terhadap apa yang mereka pelajari melalui cara yang menyenangkan dan tidak menakutkan.

\section{DAFTAR PUSTAKA}

Arsyad, A. (2011). Media Pembelajaran. Jakarta: Rajawali Pers.

Dirmansyah, Kaswari, Mastar Asran. (2014). Efektifitas Peningkatan Aktivitas Belajar Ipa Dengan Metode Active Learning Tipe Team Quiz Di Sd.Pontianak.

(jurnal.untan.ac.id/index.php/jpdpb/article/view/853 Diakses pada 15 Oktober 2015)

Djamarah, Syaiful Bahri dan Aswan Zain. (2010). Strategi Belajar Mengajar.Jakarta: Rineka Cipta.

Hamalik, Oemar. (2009). Kurikulum dan Pembelajaran. Jakarta: Bumi Aksara. 
Hollingsworth P., Lewis G. (2008). Pembelajaran Aktif. PT. Indeks

Maisaroh, S.E.,MSi.dkk. (2010). Peningkatan Hasil Belajar Siswa Dengan Menggunakan Metode Pembelajaran Active Learning Tipe Quiz Team Pada Mata Pelajaran Keterampilan Dasar Komunikasi Di SMK Negeri 1 Surabaya. (http://journal.uny.ac.id/index.php/jep/article/viewFile/571/327 Diakses pada 1 Oktober 2015)

Purwanto. (2011). Evaluasi Hasil Belajar. Yogyakarta: Pustaka Pelajar.

Rahmah Julfitriah Tampubolon. (2013). Efektifitas Penggunaan Metode Quiz Team Terhadap Kemampuan Menentukan Unsur Intrinsik Cerpen Siswa Kelas X Sma Negeri 1 Saipar Dolok Hole Tahun Pembelajaran 2013/2014 (jurnal.unimed.ac.id/2012/index.php/sasindo/504 Diakses pada 15 Oktober 2015)

Sagala, Syaiful. (2010). Konsep dan Makna Pembelajaran: Untuk Membantu Memecahkan Problematika Belajar dan Mengajar. Bandung: Alfabeta.

Sardiman. (2011). Interaksi dan Motivasi Belajar Mengajar. Jakarta: Rajawali Pers.

Silberman, M. (2007). Active Learning: 101 Strategi Pembelajaran Aktif. Yogyakarta: PT. Pustaka Insan Madani

Slameto. (2008). Proses Belajar Mengajar. Jakarta: Remaja Rosdakarya.

Sudjana, Nana. (2010). Penilaian Hasil Proses Belajar Mengajar. Bandung: Remaja Rosdakarya. 